\title{
And the winner is ....! A test of simple predictors of plant species richness in agricultural grasslands
}

\section{Journal Article}

\section{Author(s):}

Kleinebecker, Till; Busch, Verena; Hölzel, Norbert; Hamer, Ute; Schäfer, Deborah; Prati, Daniel; Fischer, Markus; Hemp, Andreas; Lauterbach, Ralf; Klaus, Valentin $\mathrm{H}$.

\section{Publication date:}

2018-04

\section{Permanent link:}

https://doi.org/10.3929/ethz-b-000227407

Rights / license:

Creative Commons Attribution-NonCommercial-NoDerivatives 4.0 International

Originally published in:

Ecological Indicators 87, https://doi.org/10.1016/j.ecolind.2017.12.031 


\section{And the winner is .... ! A test of simple predictors of plant species richness in}

\section{2 agricultural grasslands}

3

4

5

7

8

9 2

Till Kleinebecker ${ }^{1 *}$, Verena Busch ${ }^{1}$, Norbert Hölzel${ }^{1}$, Ute Hamer ${ }^{1}$, Deborah Schäfer ${ }^{2}$, Daniel Prati², Markus Fischer ${ }^{2}$, Andreas Hemp ${ }^{3}$, Ralf Lauterbach ${ }^{4}$, Valentin H. Klaus ${ }^{1 \#}$

${ }^{1}$ Münster University, Institute of Landscape Ecology, Heisenbergstraße2, 48149 Münster, Germany

${ }^{2}$ University of Bern, Institute of Plant Sciences, Altenbergrain 21, 3013 Bern, Switzerland

${ }^{3}$ University of Bayreuth, Department of Plant Systematics, Universitätsstraße 30, 95440 Bayreuth, Germany

${ }^{4}$ University of Ulm, Institute of Experimental Ecology, Albert-Einstein-Allee 11, 89069 Ulm, Germany

\# current address: ETH Zürich, Institute of Agricultural Sciences, Universitätstr. 2, 8092 Zürich, Switzerland

${ }^{*}$ Corresponding author:

till.kleinebecker@uni-muenster.de, Tel. +49 251 8339766, Fax + 492518338338

\section{Keywords}

biodiversity; Ellenberg indicator value; fertilization; land-use intensity; nitrogen; phosphorus; productivity 


\section{Abstract}

Land-use intensification, nutrient enrichment and enhanced productivity levels are major drivers of the current biodiversity loss in agricultural grasslands. Although these drivers are potentially strongly causally linked, their potential to explain changes in biodiversity can enhance each other and often varies over time. Here, we explored the explanatory power of different abiotic drivers and the Ellenberg indicator value for nutrient availability to predict plant species richness using data of 150 grassland plots over seven years. The approach also allows to assess the temporal robustness of many of these drivers. Our results revealed the Ellenberg indicator value for nutrients to be the best and temporally most consistent predictor of plant species richness. Unweighted mean Ellenberg values showed an even stronger negative relationship to plant species richness than abundance weighted mean values. Direct measurements of soil and plant biomass nutrients, aboveground biomass and land-use intensity predicted plant species richness less well and showed considerable temporal variability in the respective association. In case of biomass nitrogen and phosphorus concentrations, current year weather conditions are assumed to strongly affect the strength of the relationship by shifting the phenological development considerable among sampling years. Although mainly driven by aboveground biomass, a combination of biomass nutrient concentrations with productivity, i.e. the nutrient stock in the aboveground biomass, turned out to better predict plant species richness than its single components and inter-annual variability in the relationship was markedly lower. Especially for aboveground biomass and the intensity of land-use, long-term mean values significantly improved the explanatory power compared to single year measurements. We conclude that studies explaining biodiversity changes should carefully take into account temporal variability in the drivers under study before judging the strength of a particular mechanistic relationship.

\section{Introduction}

The intensification of land use has led to worldwide changes in nutrient fluxes at the continental down to the local scale being one of the main drivers of global change (Erb et al., 2016; Smith et al., 2016). In temperate agricultural grasslands, land-use intensification and nutrient enrichment are associated with an increase in productivity and a decrease in biodiversity (Firbank et al., 2008; Kleijn et al., 2009; Socher et al., 2012). When assessing drivers of plant diversity, for example by quantifying fertilization intensity, productivity or nutrient concentrations in plant biomass and soil (Hejcman et al., 2010; Klaus et al., 2013; Oelmann et al., 2009; Socher et al., 2012), studies often rely on single year's measurements. However, 
these parameters are known to fluctuate over time (Kleinebecker et al. 2011a; Robinson et al., 2013; Thompson et al., 1997; Wilson, 2007). This variability and the resulting uncertainty strongly reduces the potential for generalization of the strength of mechanistic relationships.

As predictions on determinants of plant diversity are often based on short-term studies, they may not correctly reflect the mechanistic dependencies (Bakker et al., 1996). For example, weather conditions shortly before sampling can differ strongly among years being the main reason of inter-annual variation in nutrient supply and productivity but also affecting management decisions and thus current year's landuse intensity (Robinson et al., 2013; Wilson, 2007). Long-term studies, on the other hand, might facilitate a sound evaluation of drivers of plant diversity but are either restricted to only few target variables or in the number of independent replications. To our knowledge, long-term studies covering multiple drivers of plant species richness across a large number of grasslands with different environmental conditions are widely lacking.

Soil nutrient measurements usually provide a temporally limited insight, restricted to the time of soil sampling. However, within a vegetation period variability in soil nutrient availability can be considerable due to e.g. variation in land use, weather conditions and seasonal changes in soil biological activity (Klaus et al., 2016; Kleinebecker et al., 2011a; Regan et al., 2014). To account for this seasonal variability, ion exchange resin (IER) bags are an effective way to assess soil nutrient availability over a longer time span (e.g. Binkley \& Matson, 1983; Salmon et al., 2016). Similarly, nitrogen (N) and phosphorus $(\mathrm{P})$ concentrations in foliar plant biomass and respective nutrient stocks in the aboveground biomass can also be used as indicators for the relative availability of $\mathrm{N}$ and $\mathrm{P}$ in the soil, pinpointing the nature of nutrient limitation and thus productivity regulation at community level (Klaus et al., 2011; Oelmann et al., 2009; Olde Venterink et al., 2003). In the absence of direct measurements of abiotic factors, or in addition to them, the Ellenberg indicator value for nutrient supply (Ellenberg, 1974, hereafter referred to as Ellenberg $\mathrm{N}$ ) is an easy method to characterize site condition in terms of nutrient supply and productivity from vegetation records (Diekmann, 2003; Wagner et al. 2007). In Central Europe, Ellenberg indicator values (Ellenberg et al., 1992) are a well-established tool to assess plant diversity-environment relationships in conservation ecology. For plant species with a realized niche optimum in terms of, in our case, nutrient supply, this optimum is given on an ordinal scale ranging from one to nine. Trophic conditions can then be characterized by the calculation of unweighted or abundance-weighted mean Ellenberg $\mathrm{N}$ values based on the plant species composition (e.g. Diekmann, 2003; Duprè et al., 2010; Klaus et al., 2012). 
1 We related multiple drivers of plant diversity and indicators of these drivers to the plant species richness

2 in diversely managed grasslands (i.e. $\mathrm{NO}_{3}-\mathrm{N}, \mathrm{NH}_{4}-\mathrm{N}$ and $\mathrm{PO}_{4}-\mathrm{P}$ availability in soil using IER bags, aboveground community biomass as a measure for productivity, $\mathrm{N}$ and $\mathrm{P}$ concentrations and their stocks in aboveground biomass, the intensity of land use (fertilizer application, mowing frequency and livestock grazing), and weighted and unweighted Ellenberg $\mathrm{N}$ values). Our data set comprises 150 grasslands from three regions in Germany and covers seven years (except soil nutrients, which were measured in one year only). We addressed the following main questions:

(1) Which measure predicts plant species richness best?

(2) How consistent is the predictive power across years; i.e. which variable is the most reliable in terms of inter-annual variability?

\section{Methods}

\subsection{Study regions}

Our study was performed in the framework of the so-called Biodiversity Exploratories for long-term functional biodiversity research (www.biodiversity-exploratories.de). The three study regions reflect a gradient of rising altitude, increasing precipitation and slightly decreasing annual mean temperatures from northeastern to southwestern Germany (Table S1, Fischer et al., 2010). In each of the three regions, 50 grasslands were selected along a gradient of land-use intensity. Mean and range of landuse intensities were comparable among regions and representative for large parts of Central European grassland management (Blüthgen et al., 2012). The gradient ranged from unfertilized sheep pastures and meadows cut once a year up to highly fertilized meadows with three cuts per year and mown pastures, where mowing and intensive grazing were combined (Fischer et al. 2010).

\subsection{Vegetation sampling and biomass analyses}

We recorded all vascular plant species and estimated their percentage cover on permanent plots $(4 \mathrm{~m}$ × $4 \mathrm{~m}$ ) annually in May or early June from 2009 to 2015 on all 150 grasslands. To provide a robust measure for further analyses, we calculated a mean value of plant species richness per plot across years. Based on the vegetation records, unweighted and abundance-weighted mean Ellenberg $\mathrm{N}$ values were calculated as surrogates for nutrient supply (Ellenberg et al., 2001). Simultaneously with the vegetation recording, aboveground plant community biomass was harvested in eight quadrats of 0.25 
$1 \mathrm{~m}^{2}$ each adjacent to the respective vegetation record. Temporary fences ensured that plots were not 2 mown or grazed before biomass sampling took place. Plant material was dried for $48 \mathrm{~h}$ at $80^{\circ} \mathrm{C}$ and weighed to the nearest gram, providing an estimate of grassland productivity for each year. Afterwards, biomass was analysed for $\mathrm{N}$ and $\mathrm{P}$ concentrations by means of near infrared reflectance spectroscopy (Spectra Star 2400, Unity Scientific, Columbia, MD, USA). For methodological details see Kleinebecker et al. (2011b). In addition to $\mathrm{N}$ and $\mathrm{P}$ concentrations, we calculated $\mathrm{N}$ and $\mathrm{P}$ stocks (and their sum) by multiplying the respective concentrations with aboveground biomass.

\subsection{Soil nutrient analyses}

Soil nutrient concentrations were measured in situ using IER bags. IER bags were buried in March 2015 at $20 \mathrm{~cm}$ depth and taken out in early August. In the study regions Schwäbische Alb and Hainich, in some very shallow soils, bags were buried at a depth of $12-15 \mathrm{~cm}$ instead. To account for spatial variability, three bags were placed as replicates at every plot and concentrations were averaged. IER bags contained anion/cation mixed-bed resin beads plus specific resin beads for phosphate (TerrAquat, Nürtingen, Germany). After removal, resin bags were stored in a dark and cool place. To determine $\mathrm{NH}_{4}-\mathrm{N}$ and $\mathrm{NO}_{3}-\mathrm{N}$, an aliquot of $15 \mathrm{~g}$ resin was extracted with $100 \mathrm{ml} 1 \mathrm{M} \mathrm{NaCl}$ in two steps of two parallels of $50 \mathrm{ml}$ each, shaked for $30 \mathrm{~min}$ and filtered. To determine $\mathrm{PO}_{4}-\mathrm{P}$, another aliquot of the resin beads $\left(15 \mathrm{~g}\right.$ ) was extracted according to the same protocol but with $100 \mathrm{ml} 0.5 \mathrm{M} \mathrm{H}_{2} \mathrm{SO}_{4}$ as extraction agent. Measurement of $\mathrm{NH}_{4}-\mathrm{N}, \mathrm{NO}_{3}-\mathrm{N}$ and $\mathrm{PO}_{4}-\mathrm{P}$ was performed with a Continuous Flow Auto Analyser (Skalar Analytic $\mathrm{GmbH}$, The Netherlands). All concentrations are given in $\mathrm{mg}^{*} \mathrm{~g}^{-1}$ (dry weight) resin.

\subsection{Land-use information}

For quantification of the intensity of land use, we used questionnaires to gather information from farmers on the annual amount of fertilizer applied ( $\mathrm{kg}$ nitrogen $\left.\times \mathrm{ha}^{-1}\right)$, the frequency of mowing (number of cuts) and the grazing intensity (number of livestock units $\times$ grazing days $\times$ ha $^{-1}$ ) on each grassland. The intensities of the three land-use components were standardized by dividing raw values by the overall mean. In addition, we calculated an integrative land-use intensity index (LUI) as the square root of the sum of the three standardized single components (for further details see Blüthgen et al., 2012).

\subsection{Statistics}


1 We calculated linear mixed-effects models to relate the long-term average of plant species richness to

2 our set of predictor variables using the Imer function implemented in the Ime4 R package (Bates et al.,

3 2015). Study region was set as random factor to account for regional peculiarities and differences in the species pool (Klaus et al., 2013). Analyses were performed for each year separately and for the longterm mean of the respective variable. We calculated the marginal $R^{2}$ to quantify the proportion of variance explained by the fixed factor for each model in line with the method presented by Nakagawa and Schielzeth (2013) and implemented in the MuMln package (Barton, 2015). Variables were log transformed where necessary to achieve normal distribution. Model assumptions were checked with diagnostic plots. For variables where long-term data was available, we calculated the coefficient of variance of model $R^{2}$ values to quantify the robustness of the respective predictor variable across years. To check inter-correlations among variables we applied a Spearman rank correlation to the data obtained in 2015; the year for which all variables were available.

\section{Results}

The vast majority of the studied drivers of plant diversity were significantly positively inter-correlated (Table 1). All variables were constantly negatively related to plant species richness, except grazing intensity, which did not show a significant relationship with plant species richness (Table 2, 3). The strength of this relationship differs among regions with generally lower performance of the tested predictors in Schorfheide (Figures S1, S2, S3). The by far strongest predictor of plant diversity in 2015 (and across all years) turned out to be Ellenberg $N$ (weighted: $R^{2}=0.43$, unweighted: $R^{2}=0.52$ ), followed by land-use intensity (particularly mowing, $\left.R^{2}=0.15\right)$ and aboveground biomass $\left(R^{2}=0.12\right)$. Both, $N$ and $\mathrm{P}$ concentrations in plant biomass and soil were surprisingly poor predictors. Only biomass $\mathrm{P}$ concentrations and resin $\mathrm{NO}_{3}-\mathrm{N}$ reached $\mathrm{R}^{2}$ values close to 0.10 and were significant at $P<0.001$ (Table 2, Figure 1). Nitrogen and $P$ stocks were markedly better predictors of plant species richness than the respective nutrient concentration and even better than the aboveground biomass alone $\left(R^{2}=0.26\right.$, $R^{2}=0.20$ and $R^{2}=0.26$, respectively), although they were strongly correlated with the aboveground biomass $(R \geq 0.95$, Table 1$)$.

Variation in explanatory power across years was highest for $\mathrm{N}$ and $\mathrm{P}$ concentrations in plant biomass (Table 3, CV: 0.74 and 0.56 , respectively). For $\mathrm{N}$ concentrations, the negative relation with plant species richness in the worst performing year was particularly weak $\left(R^{2}: 0.02\right)$. Aboveground biomass also showed considerable inter-annual variation in its relation with plant species richness (CV: 0.33), as did 
fertilization intensity (CV: 0.28). Variation in explanatory power across years of nutrient stocks and the compound LUI index was considerably lower. The most consistent indicator of plant diversity turned out to be Ellenberg $N$ ( $C V$ for both weighted and unweighted: 0.07 ) with $R^{2}$ between 0.40 and 0.49 (weighted) and between 0.43 and 0.54 (unweighted) in the worst and best performing single year, respectively (Table 3 ).

Using mean values across years revealed Ellenberg $\mathrm{N}$, mowing and fertilization intensity to have a similar model performance as for the best single year (Table 3). For the LUI index, aboveground biomass and $\mathrm{N}$ and $\mathrm{P}$ stocks, the use of the long-term mean increased the explanatory power in comparison to the best performing single year. Long-term mean values of biomass nutrient concentrations performed worse than the best year but much better than the year with the lowest $R^{2}$. Thus, particularly $P$ concentrations in biomass can be a strong predictor of plant species richness, but only in particular years (Table 3, maximum $\mathrm{R}^{2}: 0.33$ ).

\section{Discussion}

With the exception of grazing intensity, all tested predictors of plant diversity in agricultural grasslands were significantly associated with decreasing plant species richness. This is in line with experimental and observational studies, where soil nutrient supply (e.g. Li et al., 2017; Janssens et al., 1998), biomass $\mathrm{N}$ and P concentrations (e.g. Fujita et al., 2014; Klaus et al. 2011), productivity (e.g. van Dobben et al., 2017; Klaus et al. 2013) and land-use intensity (e.g. Blüthgen et al., 2016; Socher et al., 2012) were shown to be negatively associated with plant diversity. However, we also observed distinct differences in the performance of individual predictors among regions. The lower performance in Schorfheide is most likely the result of a depleted regional species richness due to former intensive land use overruling effects of current land-use intensity and productivity (Klaus et al. 2013). With the exception of grazing intensity, we found all different measures or surrogates of nutrient availability to be positively interrelated indicating the robustness of single measures but also overlapping explanatory power when used in joint analyses to explain plant diversity (Kleinebecker et al., 2014). However, our study revealed that Ellenberg $\mathrm{N}$ was clearly the best predictor of plant species richness in Central European agricultural grasslands. In accordance to literature, cover-weighting did not improve (but slightly deteriorate) the predictive power of Ellenberg N (e.g. Käfer \& Witte, 2004). Contrastingly, the explanatory power of soil and biomass nutrients and land-use intensity was much lower. Better, but not as well as Ellenberg $\mathrm{N}$, performed the aboveground community biomass and especially $\mathrm{N}$ and $\mathrm{P}$ stocks therein. Similarly, 
Wagner et al. (2007) found Ellenberg $N$ to be a better predictor of productivity than direct measurements of soil variables, assumingly due to the integration of multiple factors influencing productivity such as nutrient availability but also water supply and soil $\mathrm{pH}$. Although Ellenberg $\mathrm{N}$ values directly refer to the vegetation composition (for discussion of this issue see Zelený \& Schaffers (2012), Wildi (2016) and literature therein), they were shown to be well correlated to multiple functional characteristics making them a reliable measure to understand driving mechanisms shaping the ecological niches of plants in a community when used in combination with ecophysiological determinants (Bartelheimer \& Poschlod, 2016). Another aspect that might negatively affect the performance of soil and biomass nutrients as well as aboveground biomass is that these variables were sampled at a smaller area than the vegetation, although this is common practice due to practical reasons (e.g. Janssens et al. 1998; Klaus et al. 2011; Van Dobben et al. 2017). By replicated sampling at the plot level we tackled this issue, but confounding effects due to different scales cannot be completely ruled out. In summary, however, our study provides further evidence that Ellenberg $N$ (and particularly unweighted Ellenberg $N$ ) is a simple but powerful indicator of nutrient-related drivers of plant diversity and a very useful tool for biodiversity monitoring in grasslands (Lewis et al., 2014).

Ellenberg $\mathrm{N}$ also showed best results in terms of temporal consistency in predicting plant species richness, most likely due to vegetation composition (which determines the Ellenberg $\mathrm{N}$ values) integrating trophic conditions that may strongly fluctuate in time and space despite being rather constant itself (Diekmann, 2003). In contrast, aboveground biomass and biomass $\mathrm{N}$ and $\mathrm{P}$ concentrations strongly varied across years and consequently in their explanatory power to predict plant species richness. This may be partly caused by sampling at a similar time of the year but in slightly different phenological stages, which were shown to affect particularly nutrient concentrations in plant biomass (Klaus et al., 2016; Kleinebecker et al., 2011a). Presumably more important, variable seasonal weather conditions strongly affected aboveground biomass and consequently relationships to plant diversity (e.g. Robinson et al., 2013; Wilson, 2007). Integrating N and P concentrations and aboveground biomass in $\mathrm{N}$ and $\mathrm{P}$ stocks, improved not only predictive power compared with the respective single components but also reduced inter-annual variation in the strength of the relationship to plant species richness. The strong influence of weather conditions on soil and biomass nutrients as well as biomass production is also reflected by the relatively low explanatory power of these variables in 2015. In this year, spring and early summer were particularly dry with precipitation levels considerably below the long-term mean (Figure S4), and these variables seem to be particularly sensitive to variable weather conditions. 
Interestingly, the intensity of grazing and fertilization likewise varied considerably across years, whereas mowing intensity and the LUI index (sum of the single components) were more stable resulting in more constant associations with plant species richness.

Calculating mean values of the measured variables across the seven years of monitoring improved the explanatory power for aboveground biomass, $\mathrm{N}$ and $\mathrm{P}$ stocks and the land-use intensity measures compared with the best performing year, whereas biomass nutrient concentrations in specific years predicted plant species richness much better. The latter indicates that in the case of biomass nutrients sampling of biomass in different phenological stages is probably a major cause of variation among years as nutrient concentrations, especially $\mathrm{N}$, tend to decrease with increasing biomass production (Hejcman et al., 2010). In case of biomass nutrients a consistent phenological stage early in the growing season might reflect the trophic status of a grassland best (Klaus et al., 2016a). Both, biomass production and land-use intensity also vary considerably across years (Allan et al., 2014; Pallett et. al., 2016), but mean values across multiple years presumably better reflect the environmental conditions shaping plant communities and therefore plant species richness.

\section{Conclusion}

Mean Ellenberg $\mathrm{N}$, and particularly unweighted Ellenberg $\mathrm{N}$ values, were proven to be the most powerful and consistent tool to assess the impact of nutrient supply on plant species richness by presumably best integrating various drivers of plant diversity and their temporal variation. However, Ellenberg $\mathrm{N}$ is derived from vegetation composition and is thus not completely independent from plant species richness. Moreover, Ellenberg $\mathrm{N}$ integrates multiple drivers and processes affecting plant diversity, hampering the assessment of clear mechanisms underlying diversity changes when it is used without further ecophysiological determinants such as trait information. Identifying individual processes and their effect size by direct measurements of driving forces in a single year should on the other hand also be treated with caution. In case of biomass nutrients, current year weather conditions need to be taken into account and the phenological development during sampling can also strongly affect the explanatory power to predict plant species richness. For aboveground community biomass, biomass nutrient stocks and the intensity of land use, long-term mean values significantly improve their performance to predict plant species richness as they better reflect conditions that resulted in the current vegetation composition and thus plant species richness. 


\section{Acknowledgements}

All analyses of this study were carried out in the laboratory of the institute of Landscape Ecology. We thank the lab-team especially Ulrike Berning-Mader, Melanie Tappe and Lennart Friedritz for help with chemical analyses and Judith Hinderling, Svenja Kunze, Martin Freitag, Dirk Trompeter, Ann-Kathrin Will and Melanie Eckert for help during field and lab work. Two anonymous reviewers greatly improved the quality of the manuscript. We also thank the managers of the three Exploratories, Kirsten ReichelJung, Katrin Lorenzen, Konstans Wells, Swen Renner, Sonja Gockel, Kerstin Wiesner, and Martin Gorke for their work in realizing this experiment and maintaining the plot and project infrastructure, Christiane Fischer, Maren Gleisberg and Simone Pfeiffer for giving support through the central office, Michael Owonibi and Jens Nieschulze for managing the central data base, and Markus Fischer, Eduard Linsenmair, Dominik Hessenmöller, Ingo Schöning, François Buscot, Ernst-Detlef Schulze, Wolfgang W. Weisser and the late Elisabeth Kalko for their role in setting up the Biodiversity Exploratories project. Field work permits were issued by the responsible state environmental offices of Baden-Württemberg, Thüringen, and Brandenburg (according to $\S 72$ BbgNatSchG). The work has been funded by the German Research Foundation (DFG) Priority Program 1374 "Infrastructure-Biodiversity-Exploratories" (HO 3830/2-3; FI 1246/15-2; HA 4597/6-3; KL 2265/5-1).

\section{References}

Allan, E., Bossdorf, O., Dormann, C.F., Prati, D., Gossner, M., Tscharntke, T., Blüthgen, N., Bellach, M., Birkhofer, K., Boch, S., Böhm, S., Börschig, C., Chatzinotas, A., Christ, S., Daniel, R., Diekoetter, T., Fischer, C., Friedl, T., Glaser, K., Hallman, C., Hodac, L., Hölzel, N., Jung, K., Klein, A.-M., Klaus, V.H., Kleinebecker, T., Krauss, J., Lange, M., Morris, E.K., Müller, J., Nacke, H., Pašalic, E., Rillig, M., Rothenwöhrer, C., Schall, P., Scherber, C., Schulze, W., Socher, S., Steckel, J., Steffan-Dewenter, I., Türke, M., Weiner, C.N., Werner, M., Westphal, C., Wolters, V., Wubet, T., Gocke, S., Gorke, M., Hemp, A., Renner, S.C., Schöning, I., Pfeiffer, S., König-Ries, B., Buscot, F., Linsenmair, K.-E., Schulze, E.-D., Weisser, W.W., Fischer, M., 2014. Inter-annual variation in land-use intensity enhances grassland multidiversity. P. Natl. Acad. Sci. USA 111, 308-313.

Bakker, J.P., Olff, H., Willems, J.H., Zobel, M., 1996. Why do we need permanent plots in the study of long-term vegetation dynamics? J. Veg. Sci. 7, 147-155.

Bartelheimer, M., Poschlod, P., 2016. Functional characterizations of Ellenberg indicator values - a review on ecophysiological determinants. Funct. Ecol. 30, 506-516.

Barton, K., 2015. MuMIn: Multi-Model Inference. Available at: http://cran.r-project. org/web/packages/MuMIn/ accessed 3 May 2017. 
Bates, D., Maechler, M., Bolker, B., Walker, S., 2015. Fitting Linear Mixed-Effects Models Using Ime4. J. Stat. Softw. 67, 1-48.

Binkley, D., Matson, P., 1983. Ion exchange resin bag method for assessing forest soil nitrogen availability. Soil Sci. Soc. Am. J. 47, 1050-1052.

Blüthgen, N., Dormann, C., Prati, D., Klaus, V.H., Kleinebecker, T., Hölzel, N., Alt, F., Boch, S., Gockel, S., Hemp, A., Müller, J., Nieschulze, J., Renner, S.C., Schöning, I., Schumacher, U., Socher, S.A., Wells, K., Birkhofer, K., Buscot, F., Oelmann, Y., Rothenwöhrer, C., Scherber, C., Tscharntke, T., Weiner, C., Fischer, M., Kalko, E.K.V., Linsenmair, K.E., Schulze, E.-D., Weisser, W.W., 2012. A quantitative index of land-use intensity in grasslands: integrating mowing, grazing and fertilization. Basic Appl. Ecol. 13, 207-220.

Blüthgen, N., Simons, N., Jung, K., Prati, D., Renner, S., Boch, S., Fischer, M., Hölzel, N., Klaus, V.H., Kleinebecker, T., Tschapka, M., Weisser, W.W., Gossner, M.M., 2016. Land use imperils plant and animal community stability through changes in asynchrony rather than diversity. Nature Com. 7 , 10697.

Diekmann, M., 2003. Species indicator values as an important tool in applied plant ecology - a review. Basic Appl. Ecol. 4, 493-506.

Duprè, C., Stevens, C.J., Ranke, T., Bleekers, A., Peppler-Lisbach, C., Gowing, D.J.G., Diese, N.B., Dorland, E., Bobbink, R., Diekmann, M., 2010. Changes in species richness and composition in European acidic grasslands over the past 70 years: the contribution of cumulative atmospheric nitrogen deposition. Global Change Biol. 16, 344-357.

Ellenberg, H., 1974. Zeigerwerte der Gefäßpflanzen Mitteleuropas. Scr. Geobot. 9, 1-97.

Ellenberg, H., Weber, H.E., Düll, R., Wirth, V., Werner, W., Paulissen, D., 2001. Zeigerwerte von Pflanzen in Mitteleuropa, third ed. Scr. Geobot. 18, 1-248.

Erb, K.H., Luyssaert, S., Meyfroidt, P., Pongratz, J., Don, A., Kloster, S., Kuemmerle, T., Fetzel, T., Fuchs, R., Herold, M., Haberl, H., Jones, C.D., Marín-Spiotta, E., McCallum, I., Robertson, E., Seufert, V., Fritz, S., Valade, A., Wiltshire, A., Dolman, A.J., 2017. Land management: data availability and process understanding for global change studies. Global Change Biol. 23, 512-533.

Firbank, L.G., Petit, S., Smart, S., Blain, A., Fuller, R.J., 2008. Assessing the impacts of agricultural intensification on biodiversity: a British perspective. Philos. T. R. Soc. B, 363, 777-787.

Fischer, M., Bossdorf, O., Gockel, S., Hänsel, F., Hemp, A., Hessenmöller, D., Korte, G., Nieschulze, J., Pfeiffer, S., Prati, D., Renner, S., Schöning, I., Schumacher, U., Wells, K., Buscot, F., Kalko, E.K.V., Linsenmair, K.E., Schulze, E.-D., Weisser, W.W., 2010. Implementing large-scale and long-term functional biodiversity research: the biodiversity exploratories. Basic Appl. Ecol. 11, 473-485.

Fujita, Y., Olde Venterink, H., van Bodegom, P.M., Douma, J.C., Heil, G.W., Hölzel, N., Jabłońska, E., Kotowski, W., Okruszko, T., Pawlikowski, P., de Ruiter, P.C., Wassen, M.J., 2014. Low investment in sexual reproduction threatens plants adapted to phosphorus limitation. Nature 505, 82-86. 
Hejcman, M., Szaková, J., Schellberg, J., Tlustoš, P., 2010. The Rengen grassland experiment: relationship between soil and biomass chemical properties, amount of elements applied, and their uptake. Plant Soil 333, 163-179.

Janssens, F., Peeters, A., Tallowin, J.R.B., Bakker, J.P., Bekker, R.M., Fillat, F., Oomes, M.J.M., 1998.

Relationship between soil chemical factors and grassland diversity. Plant Soil 202, 69-78.

Käfer, J., Witte, J-P.M., 2004. Cover-weighted averaging of indicator values in vegetation analyses. J. Veg. Sci. 15, 647-652.

Klaus, V.H., Kleinebecker, T., Hölzel, N., Blüthgen, N., Boch, S., Müller, J., Socher, S.A., Prati, D., Fischer, M., 2011. Nutrient concentrations and fibre contents of plant community biomass reflect species richness patterns along a broad range of land-use intensities among agricultural grasslands. Perspect Plant Ecol. Evol. Syst. 13, 287-295.

Klaus, V.H., Kleinebecker, T., Boch, S., Müller, J., Socher, A.S., Prati, D., Fischer, M., Hölzel, N., 2012. NIRS meets Ellenberg's indicator values: Prediction of moisture and nitrogen values of agricultural grassland vegetation by means of near-infrared spectral characteristics. Ecol. Indic. 14, 82-86

Klaus, V.H., Hölzel, N., Boch, S., Müller, J., Socher, S.A., Prati, D., Fischer, M., Kleinebecker, T., 2013. Direct and indirect associations between plant species richness and productivity in grasslands: regional differences preclude simple generalization of productivity-biodiversity relationships. Preslia $85,97-112$.

Klaus, V.H., Boch, S., Boeddinghaus, R.S., Hölzel, N., Kandeler, E., Marhan, S., Oelmann, Y., Prati, D., Regan, K.M., Schmitt, B., Sorkau, E., Kleinebecker, T., 2016 Temporal and small-scale spatial variation in grassland productivity, biomass quality and nutrient limitation. Plant Ecol. 217, 843-856.

Kleijn, D., Kohler, F., Báldi, A., Batáry, P., Concepción, E.D., Clough, Y., Díaz, M., Gabriel, D., Holzschuh, A., Knop, E., Kovács, A., Marshall, E.J.P., Tscharntke, T., Verhulst, J., 2009. On the relationship between farmland biodiversity and land-use intensity in Europe. P. R. Soc. B 276, 903909.

Kleinebecker, T., Weber, H., Hölzel, N., 2011a. Effects of grazing on seasonal variation of aboveground biomass quality in calcareous grasslands. Plant Eco. 212, 1563-1576

Kleinebecker, T., Klaus, V.H., Hölzel, N., 2011b. Reducing sample quantity and maintaining high prediction accuracy of quality parameters in grassland biomass with near-infrared reflectance spectroscopy NIRS. J. Near Infrared Spec. 19, 495-505

Kleinebecker, T., Hölzel, N., Prati, D., Schmitt, B., Fischer, M., Klaus, V.H., 2014. Evidence from the real world: $15 \mathrm{~N}$ natural abundances reveal enhanced nitrogen use at high plant diversity in Central European grasslands. J. Ecol. 102, 456-465.

Lewis, R.J., Pakeman, R.J., Angus, S., Marrs, R.H., 2014. Using compositional and functional indicators for biodiversity conservation monitoring of semi-natural grasslands in Scotland. Biol. Conserv. 175, 82-93.

Li, J., Zheng, Z., Xie, H., Zhao, N., Gao, Y., 2017. Increased soil nutrition and decreased light intensity drive species loss after eight years grassland enclosures. Scientific Reports 7, 44525. 
Nakagawa, S., Schielzeth, H., 2013. A general and simple method for obtaining R2 from generalized linear mixed-effects models. Methods Ecol. Evol. 4, 133-142.

Oelmann, Y., Broll, G., Hölzel, N., Kleinebecker, T., Vogel, A., Schwartze, P., 2009. Nutrient impoverishment and limitation of productivity after 20 years of conservation management in wet grasslands of north-western Germany. Biol. Conserv. 142, 2941-2948.

Olde Venterink, H., Wassen, M.J., Verkroost, A.W.M., de Ruiter, P.C., 2003. Species RichnessProductivity Patterns Differ between N-, P-, and K-Limited Wetlands. Ecology 84, 2191-2199.

Pallett, D.W., Pescott, O.L., Schäfer, S.M., 2016. Changes in plant species richness and productivity in response to decreased nitrogen inputs in grassland in southern England. Ecol. Indic. 68, 73-81.

Regan, K.M., Nunan, N., Boeddinghaus, R., Baumgartner, V., Berner, D., Boch, S., Oelmann, Y., Overmann, J., Prati, D., Schloter, M., Schmitt, B., Sorkau, E., Steffens, M., Kandeler, E., Marhan, S., 2014. Seasonal controls on grassland microbial biogeography: Are they governed by plants, abiotic properties or both? Soil Biol Biochem 71, 21-30.

Robinson, T.M.P., La Pierre, K.J., Vadeboncoeur, M.A., Byrne, K.M., Thomey, M.L., Colby, S. E., 2013. Seasonal, not annual precipitation drives community productivity across ecosystems. Oikos $122,727-$ 738.

Salmon, V.G., Soucy, P., Mauritz, M., Celis, G., Natali, S.M., Mack, M.C., Schuur, E.A., 2016. Nitrogen availability increases in a tundra ecosystem during five years of experimental permafrost thaw. Global Change Bio. 22, 1927-1941.

Smith, P., House, J. I., Bustamante, M., Sobocká, J., Harper, R., Pan, G., West, P.C., Clark, J.M., Adhya, T., Rumpel, C. Paustian, K., Kuikman, P., Cotrufo, M.F., Elliott, J.A., McDowell, R., Griffith, R.I., Asakawa, S., Bondeau, A., Jain, A.K., Meersmans, J., Pugh, T.A.M., 2016. Global change pressures on soils from land use and management. Global Change Biol. 22, 1008-1028.

Socher, S., Prati, D., Müller, J., Klaus, V.H., Hölzel, N., Fischer, M., 2012. Direct and productivitymediated indirect effects of fertilization, mowing and grazing intensities on grassland plant species richness. J. Ecol. 100, 1391-1399.

Thompson, K., Parkinson, J.A., Band, S.R., Spencer, R.E., 1997. A comparative study of leaf nutrient concentrations in a regional herbaceous flora. New Phytol. 136, 679-689.

Van Dobben, I.F., Wamelink, G.W.W., Slim, P.A., Kaminski, J., Piorkowski, H., 2017. Species-rich grassland can persist under nitrogen-rich but phosphorus-limited conditions. Plant Soil 411, 451-466.

Wagner, M., Kahmen, A., Schlumprecht, H., Audorff, V., Perner, J., Buchmann, N., Weisser, W.W., 2007. Prediction of herbage yield in grassland: how well do Ellenberg $\mathrm{N}$-values perform? Appl. Veg. Sci. 10, 15-24.

Wildi, O. 2016. Why mean indicator values are not biased. J. Veg. Sci. 27, 40-49.

Wilson, S.D., 2007. Competition, resources, and vegetation during 10 years in native grassland. Ecology 88, 2951-2958.

Zelený, D., Schaffers, A.P. 2012. Too good to be true: pitfalls of using mean Ellenberg indicator values in vegetation analyses. J. Veg. Sci. 23, 419-431. 


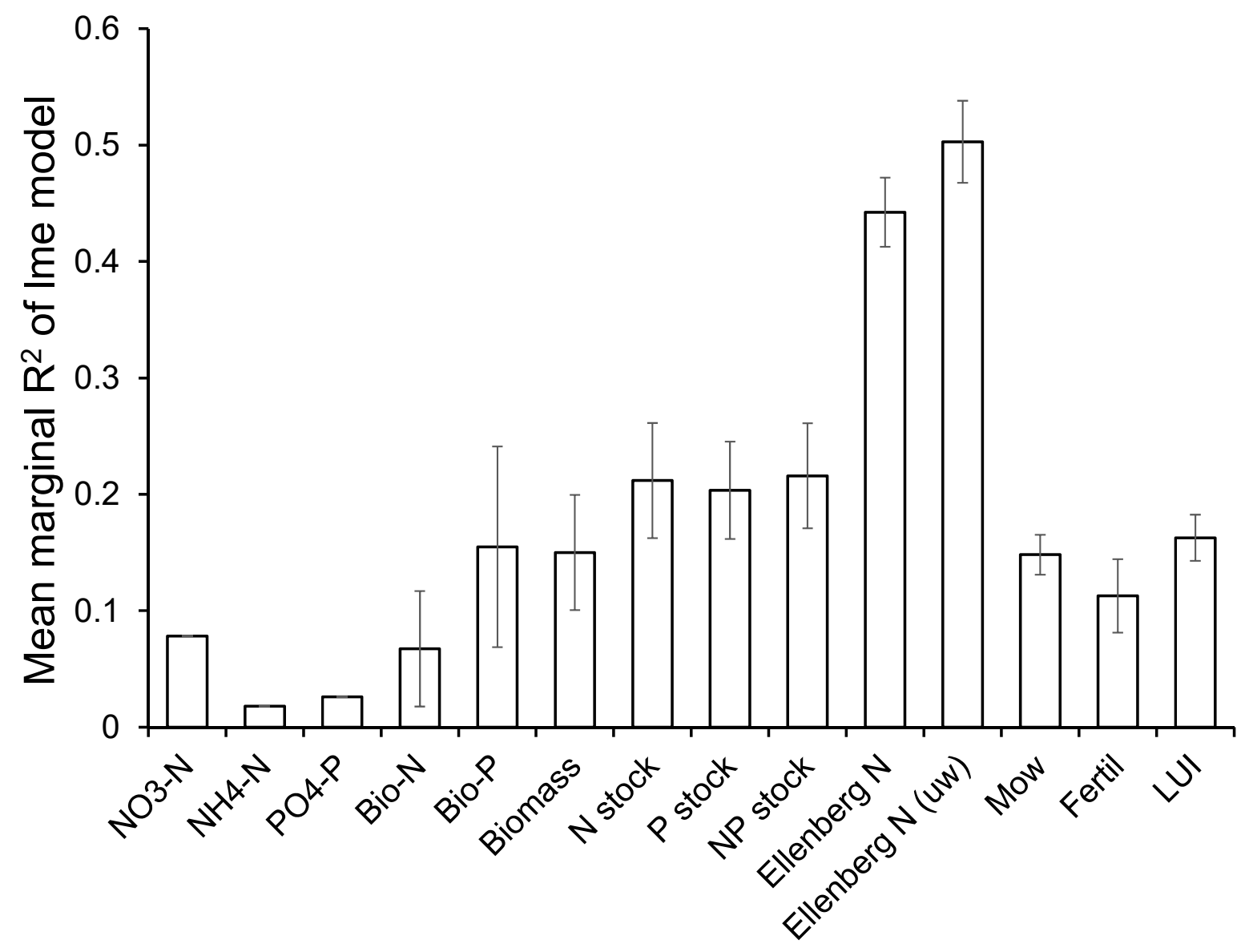

2 Figure 1 Mean $\mathrm{R}^{2}$-values and the standard deviation derived from separate linear mixed effect models 3 for all plant diversity indicators measured annually from 2009 to 2015 with plant species richness as 4 response variable and study region as random factor. For abbreviations, see Table 1. Grazing intensity revealed no significant model result and is not shown. For soil nutrients the value of 2015 is visualized. 
Table 1 Spearman correlation coefficients of plant diversity indicators in 2015. $\mathrm{NO}_{3}-\mathrm{N}, \mathrm{NH}_{4}-\mathrm{N}, \mathrm{PO}_{4}-\mathrm{P}$ : soil nitrate $\mathrm{N}$, soil ammonium $\mathrm{N}$ and soil phosphate $\mathrm{P}$ extracted from resin bags $\left[\mathrm{mg}^{*} \mathrm{~g}^{-1}\right.$ (dry weight) resin]; Bio-N, Bio-P: nitrogen and phosphorus concentration in the aboveground community biomass [\%];Biomass: aboveground biomass $\left[\mathrm{g}^{*} \mathrm{~m}^{-2}\right]$; $\mathrm{N}$ stock, $\mathrm{P}$ stock, NP stock: stocks of nutrients in the aboveground biomass $\left[\mathrm{g}^{*} \mathrm{~m}^{-2}\right]$; Ellenberg $\mathrm{N}$ : abundance weighted community mean of the Ellenberg nutrient value; Ellenberg $\mathrm{N}$ (uw): unweighted community mean of the Ellenberg nutrient value; Graz, Mow, Fertil: Intensity of grazing [LSU*days $\left.{ }^{*} a^{-1}\right]$, mowing [cuts ${ }^{*} \mathrm{~m}^{-2}$ ], fertilization $\left(\mathrm{kg} \mathrm{N}^{*} \mathrm{ha}^{-1 *} \mathrm{a}^{-1}\right)$; LUI: sum of the standardized intensities of grazing, mowing and fertilization. Note: significance levels were not corrected for multiple testing. $p \geq 0.05=N S ; 0.05>p \geq 0.01={ }^{*} ; 0.01>p \geq 0.001={ }^{* *} ; p<0.001=$ ${ }^{* * *}$. Correlation coefficients $\geq 0.4$ are given in bold.

\begin{tabular}{|c|c|c|c|c|c|c|c|c|c|c|c|c|c|c|}
\hline & $\mathrm{NO}_{3}-\mathrm{N}$ & $\mathrm{NH}_{4}-\mathrm{N}$ & $\mathrm{PO}_{4}-\mathrm{P}$ & Bio-N & Bio-P & $\begin{array}{c}\text { Bio- } \\
\text { mass }\end{array}$ & $\begin{array}{c}\mathrm{N} \\
\text { stock }\end{array}$ & $\begin{array}{c}P \\
\text { stock }\end{array}$ & $\begin{array}{c}\text { NP } \\
\text { stock }\end{array}$ & $\begin{array}{c}\text { Ellen } \\
\text { berg } \\
\mathbf{N}\end{array}$ & $\begin{array}{c}\text { Ellenb } \\
\text { erg } N \\
\text { (uw) }\end{array}$ & Graz & Mow & Fertil \\
\hline $\mathrm{NH}_{4}-\mathrm{N}$ & $0.37^{\star * *}$ & & & & & & & & & & & & & \\
\hline $\mathrm{PO}_{4}-\mathrm{P}$ & $0.27^{\star \star *}$ & $0.44^{* * *}$ & & & & & & & & & & & & \\
\hline Bio-N & $0.32^{\star \star *}$ & NS & NS & & & & & & & & & & & \\
\hline Bio-P & $0.38^{* \star *}$ & NS & NS & $0.68^{\star * *}$ & & & & & & & & & & \\
\hline Biomass & $0.25^{\star \star}$ & NS & NS & NS & NS & & & & & & & & & \\
\hline N stock & $0.34^{\star \star *}$ & NS & NS & $0.24^{* *}$ & NS & $0.95^{\star \star \star}$ & & & & & & & & \\
\hline P stock & $0.31^{* * *}$ & NS & $0.18^{*}$ & NS & $0.16^{*}$ & $0.97^{\star \star *}$ & $0.97^{\star * *}$ & & & & & & & \\
\hline NP stock & $0.34^{* * *}$ & NS & NS & $0.22^{\star *}$ & NS & $0.95^{\star * *}$ & $1.00^{\star * *}$ & $0.98^{* * *}$ & & & & & & \\
\hline Ellenberg $\mathrm{N}$ & $0.45^{\star \star *}$ & NS & $0.18^{*}$ & $0.20^{*}$ & $0.42^{\star \star *}$ & $0.47^{\star \star *}$ & $0.53^{* * *}$ & $0.54^{\star \star *}$ & $0.53^{* * *}$ & & & & & \\
\hline Ellenberg $\mathbf{N}$ (uw) & $0.45^{\star \star \star}$ & NS & 0.12 & $0.30^{* * *}$ & $0.41^{* * *}$ & $0.48^{\star * *}$ & $0.58^{\star * *}$ & $0.55^{\star \star *}$ & $0.57^{\star \star \star}$ & $0.83^{* \star *}$ & & & & \\
\hline Graz & NS & NS & NS & NS & $0.23^{* *}$ & NS & NS & NS & NS & NS & NS & & & \\
\hline Mow & $0.21^{*}$ & $0.21^{\star *}$ & $0.27^{\star * *}$ & NS & NS & NS & NS & NS & NS & $0.26^{\star *}$ & $0.28^{* \star *}$ & - & & \\
\hline Fertil & $0.35^{\star \star \star}$ & $0.31^{* * *}$ & $0.46^{\star * \star}$ & NS & $0.18^{*}$ & $0.16^{*}$ & $0.18^{*}$ & $0.20^{*}$ & $0.18^{*}$ & $0.26^{* *}$ & $0.26^{\star *}$ & $-0.23^{* *}$ & $0.51^{* * *}$ & \\
\hline LUI & $0.46^{* * *}$ & NS & $0.41^{* * *}$ & NS & $0.30^{* * *}$ & $0.37^{* * *}$ & $0.40^{*}$ & $0.42^{\star}$ & $0.40^{*}$ & $0.47^{* * *}$ & $0.43^{\star * *}$ & NS & $0.50^{* * *}$ & $0.73^{\star \star *}$ \\
\hline
\end{tabular}

Table 2 Summary outputs of separate linear mixed effect models for all plant diversity indicators measured in 2015 with plant species richness as response variable and study region as random factor. For abbreviations, see Table 1.

\begin{tabular}{lccc}
\hline & t-value & $\boldsymbol{P}$ & $\mathbf{R}^{2}$ \\
\hline NO $_{3}-\mathbf{N}$ & -4.605 & $<0.001$ & 0.078 \\
$\mathbf{N H}_{4}-\mathbf{N}$ & -2.075 & 0.040 & 0.018 \\
$\mathbf{P O}_{4}-\mathbf{P}$ & -2.503 & 0.013 & 0.026 \\
Bio-N & -2.280 & 0.024 & 0.022 \\
Bio-P & -4.852 & $<0.001$ & 0.094 \\
Biomass & -4.549 & $<0.001$ & 0.124 \\
$\mathbf{N}$ stock & -6.765 & $<0.001$ & 0.260 \\
$\mathbf{P}$ stock & -5.887 & $<0.001$ & 0.203 \\
NP stock & -6.701 & $<0.001$ & 0.257 \\
Ellenberg N & -13.110 & $<0.001$ & 0.432 \\
Ellenberg N (uw) & -15.970 & $<0.001$ & 0.523 \\
Graz & & $\mathrm{NS}$ & \\
Mow & -7.377 & $<0.001$ & 0.152 \\
Fertil & -4.996 & $<0.001$ & 0.086 \\
LUI & -6.832 & $<0.001$ & 0.144 \\
\hline
\end{tabular}


1 Table 3 Summary outputs of separate linear mixed effect models for all plant diversity indicators 2 measured annually from 2009 to 2015 with plant species richness as response variable and study region 3 as random factor. For each indicator, model statistics for long-term mean values, the best and the worst 4 performing year are displayed. For abbreviations, see Table 1. CV (data): mean ( $\mathrm{min} / \mathrm{max})$ coefficient 5 of variation of variables across years; $C V\left(R^{2}\right)$ : $C V$ of the explained variance of variables across years.

\begin{tabular}{|c|c|c|c|c|c|}
\hline & t-value & $\boldsymbol{P}$ & $\mathbf{R}^{2}$ & CV (data) & $\mathrm{CV}\left(\mathbf{R}^{2}\right)$ \\
\hline Bio-N & & & & $0.15(0.06 / 0.32)$ & 0.739 \\
\hline Mean value accross years & -5.388 & $<0.001$ & 0.125 & & \\
\hline Best performing single year & -6.100 & $<0.001$ & 0.155 & & \\
\hline Worst performing single year & -2.280 & 0.024 & 0.022 & & \\
\hline Bio-P & & & & $0.10(0.03 / 0.25)$ & 0.557 \\
\hline Mean value accross years & -7.969 & $<0.001$ & 0.219 & & \\
\hline Best performing single year & -9.106 & $<0.001$ & 0.334 & & \\
\hline Worst performing single year & -4.519 & $<0.001$ & 0.088 & & \\
\hline Biomass & & & & $0.42(0.09 / 1.19)$ & 0.330 \\
\hline Mean value accross years & -8.895 & $<0.001$ & 0.258 & & \\
\hline Best performing single year & -8.070 & $<0.001$ & 0.217 & & \\
\hline Worst performing single year & -4.742 & $<0.001$ & 0.091 & & \\
\hline N stock & & & & $0.40(0.12 / 1.05)$ & 0.233 \\
\hline Mean value accross years & -11.110 & $<0.001$ & 0.361 & & \\
\hline Best performing single year & -9.763 & $<0.001$ & 0.292 & & \\
\hline Worst performing single year & -7.110 & $<0.001$ & 0.159 & & \\
\hline P stock & & & & $0.40(0.11 / 1.12)$ & 0.205 \\
\hline Mean value accross years & -10.630 & $<0.001$ & 0.326 & & \\
\hline Best performing single year & -9.222 & $<0.001$ & 0.278 & & \\
\hline Worst performing single year & -6.715 & $<0.001$ & 0.161 & & \\
\hline NP stock & & & & $0.40(0.12 / 1.06)$ & 0.209 \\
\hline Mean value accross years & -11.130 & $<0.001$ & 0.359 & & \\
\hline Best performing single year & -9.763 & $<0.001$ & 0.293 & & \\
\hline Worst performing single year & -6.325 & $<0.001$ & 0.168 & & \\
\hline Ellenberg $\mathbf{N}$ & & & & $0.05(0.01 / 0.14)$ & 0.067 \\
\hline Mean value accross years & -14.660 & $<0.001$ & 0.485 & & \\
\hline Best performing single year & -14.300 & $<0.001$ & 0.486 & & \\
\hline Worst performing single year & -12.330 & $<0.001$ & 0.399 & & \\
\hline Ellenberg N (uw) & & & & $0.03(0.01 / 0.14)$ & 0.070 \\
\hline Mean value accross years & -15.630 & $<0.001$ & 0.538 & & \\
\hline Best performing single year & -15.640 & $<0.001$ & 0.539 & & \\
\hline Worst performing single year & -12.890 & $<0.001$ & 0.434 & & \\
\hline Graz & & & & $0.57(0.00 / 2.65)$ & - \\
\hline Mean value accross years & & NS & & & \\
\hline Best performing single year & & NS & & & \\
\hline Worst performing single year & & NS & & & \\
\hline Mow & & & & $0.45(0.00 / 2.65)$ & 0.116 \\
\hline Mean value accross years & -8.103 & $<0.001$ & 0.176 & & \\
\hline Best performing single year & -8.047 & $<0.001$ & 0.169 & & \\
\hline Worst performing single year & -5.930 & $<0.001$ & 0.114 & & \\
\hline Fertil & & & & $0.55(0.00 / 2.65)$ & 0.280 \\
\hline Mean value accross years & -7.842 & $<0.001$ & 0.161 & & \\
\hline Best performing single year & -7.936 & $<0.001$ & 0.164 & & \\
\hline Worst performing single year & -4.311 & $<0.001$ & 0.067 & & \\
\hline LUI & & & & $0.20(0.02 / 0.53)$ & 0.122 \\
\hline Mean value accross years & -9.148 & $<0.001$ & 0.215 & & \\
\hline Best performing single year & -8.152 & $<0.001$ & 0.187 & & \\
\hline Worst performing single year & -6.374 & $<0.001$ & 0.136 & & \\
\hline
\end{tabular}

